\title{
Intracellular free calcium related to apoptotic cell death in quail granulosa cell sheets kept in serum-free culture
}

\author{
Katharina D'Herde ${ }^{1,3}$ and Luc Leybaert ${ }^{2}$ \\ ${ }^{1}$ Department of Human Anatomy, Embryology and Histology \\ ${ }^{2}$ Laboratory of Normal and Pathological Physiology, University Gent, B-9000 \\ Gent, Belgium \\ ${ }^{3}$ corresponding author: Katharina D'Herde, MD, PhD, Department of Human \\ Anatomy, Embryology and Histology, University of Gent, Godshuizenlaan, 4 \\ B-9000 Gent, Belgium. tel: +32 9 2240224; fax: +32 9 2259452; e-mail: \\ katharina.dherde@rug.ac.be
}

Received 4.12.95; revised 3.6.96; accepted 6.6.96

Edited by M. Placentini

\begin{abstract}
The relationship between apoptosis and resting intracellular free calcium $\left(\left[\mathrm{Ca}^{2+}\right]_{\mathrm{i}}\right)$ was studied in serum-free cultures of granulosa cell sheets isolated from preovulatory quail follicles. Apoptosis was detected by acridine orange, in situ end-labeling of fragmented DNA and electron microscopy. $\left[\mathrm{Ca}^{2+}\right]_{i}$ was measured using fura-2. $\left[\mathrm{Ca}^{2+}\right]_{i}$ averaged $525 \mathrm{mM}$ in freshly isolated sheets. In $24 \mathrm{~h}$ cultures no apoptosis was detected but $\left[\mathrm{Ca}^{2+}\right]_{i}$ became very dispersed, $20 \%$ of the sheets showing values above $1000 \mathrm{nM}$. At $48 \mathrm{~h}$, apoptosis was obvious and $\left[\mathrm{Ca}^{2+}\right]_{i}$ remained dispersed. At $72 \mathrm{~h}$, apoptosis and also the fraction of sheets with high $\left[\mathrm{Ca}^{2+}\right]_{i}$ were at their maximum. At $96 \mathrm{~h}$ apoptosis was subsiding and $\left[\mathrm{Ca}^{2+}\right]_{\mathrm{i}}$ normalized. FSH depressed apoptosis and $\left[\mathrm{Ca}^{2+}\right]_{i}$ in the $72 \mathrm{~h}$ cultures. We conclude that at $24 \mathrm{~h}$ apoptosis is intitiated at high $\left[\mathrm{Ca}^{2+}\right]_{\mathrm{i}}$ foci. At later stages apoptosis is associated with high $\left[\mathrm{Ca}^{2+}\right]$, but it is not clear whether this is cause or consequence.
\end{abstract}

Keywords: follicular atresia, granulosa cells, apoptosis, intracellular free calcium, fura-2 epifluorescence

Abbreviations: GC, granulosa cell; $\left[\mathrm{Ca}^{2+}\right]_{\mathrm{i}}$, intracellular free calcium

\section{Introduction}

Hormone-dependent tissues deprived from their survival factors represent a model to study the mechanisms of physiological or active cell death. It is now established that atresia of ovarian follicles in mammalian (Hughes and Gorospe, 1991) and avian (Tilly et al, 1991) vertebrates is initiated by apoptotic cell death of the granulosa cells (Greenwald and Terranova, 1988).

Apoptotic cell death can be triggered by calcium overload as is the case for accidental cell death (Nicotera et al, 1992; Trump and Berezesky, 1995). Moreover cytoplasmic and (or) nuclear ionized calcium increases have been implicated in all phases of apoptosis (Corcoran et al, 1994; Kroemer et al, 1995; McConkey et al, 1994). A $\left[\mathrm{Ca}^{2+}\right]_{\mathrm{i}}$ rise during the induction phase may activate signal transduction pathways involving phosphatases and protein kinases. During the effector phase $\left[\mathrm{Ca}^{2+}\right]_{\mathrm{i}}$ has been proposed as a cofactor for the anti-apoptosis oncogene $\mathrm{Bcl}-2$. Finally it has been shown that $\left[\mathrm{Ca}^{2+}\right]_{i}$ is a pleiotropic activator of proteases (e.g calpain), phospholipases and nucleases during the degradation phase (Trump and Berezesky, 1995; McConkey et al, 1994). Furthermore changes in chromatin structure, chromatin unfolding and gene activation are also calcium-dependent processes (for review see Orrenius and Nicotera, 1994).

Evidence for the role of a $\left[\mathrm{Ca}^{2+}\right]_{i}$ comes from experimental work in models of apoptosis using widely differing cell types, including granulosa cells, and is based on the fact that increased $\left[\mathrm{Ca}^{2+}\right]_{i}$ can induce internucleosomal DNA cleavage in the nucleus (Cohen and Duke, 1984; Jones et al, 1989; Zeleznik et al, 1989), that calciumionophores, which increase $\left[\mathrm{Ca}^{2+}\right]_{\mathrm{i}}$ can initiate apoptosis (McConkey et al, 1989b; 1991; Ojcius et al, 1991; Takei and Endo, 1994), that calcium-chelators inhibit apoptosis (Perotti et al, 1990) and that apoptosis is often preceded by an increase of $\left[\mathrm{Ca}^{2+}\right]_{i}$ (McConkey et al, 1989a; 1990; Martikainen and Isaacs, 1990; Bellomo et al, 1992; Escargeuil-Blanc et al, 1994). However, the picture does not seem to be so clear cut, as several authors have, based on experimental work with calcium-ionophores, calcium-chelators and calcium-sensitive fluorescent dyes, proposed that apoptosis is rather linked to a decrease of $\left[\mathrm{Ca}^{2+}\right]_{\mathrm{i}}$ (ionophores-chelators: Baffy et al, 1993; calciumsensitive dyes: Bansal et al, 1990; Galli et al, 1995).

Several model systems have been used to study the molecular mechanisms of granulosa cell death including both in vivo (reviewed in Tsafriri and Braw, 1984) and in vitro models. The in vitro models are based on culturing either complete antral follicles or dissociated granulosa cells in the absence of hormones and under serum-free conditions (Tilly et al, 1992; Tilly and Tilly, 1995; Tilly et al, 1995; Chun et al, 1994; Luciano et al, 1994; Eisenhauer et al, 1995). In these models the granulosa cells or intact preovulatory follicles were isolated from ovaries of gonadotropin-primed immature rats. In the present study we have developed an in vitro model of granulosa cell death using serum-free culture of sheets of granulosa cells isolated from the largest preovulatory follicle of adult untreated quail, an approach in which the normal tissue architecture is preserved compared to the dissociated granulosa cell preparations. The aim of this work was to study the pattern of resting $\left[\mathrm{Ca}^{2+}\right]_{i}$ changes, in relation to the onset and progression of apoptotic degeneration. 


\section{Results}

\section{Viability and apoptosis (in vitro)}

Granulosa cell sheets kept in serum-free culture for $24 \mathrm{~h}$ appeared as a flat and stretched-out preparation. Careful microscopic observation did reveal a rare apoptotic cell. There was a remarkable increase in number and extent of gap junctions between adjacent cells as compared to freshly isolated granulosa cell sheets, sometimes these gap junctions could reach a length of several micrometers (Figure 1). The granulosa cells in these $24 \mathrm{~h}$ cultures typically remained attached to their basement membrane and vitelline membrane. In situ end-labeling did not show any evidence for DNA fragmentation while positive controls with DNAse treatment displayed intense staining (Figure $2 a, b$ ). Acridine orange staining revealed a normal chromatin configuration (Figure 2c).

Granulosa cell sheets cultured for 48 to $96 \mathrm{~h}$ under serum-free conditions differed macroscopically from the $24 \mathrm{~h}$ cultures in that these sheets progressively changed from a stretched to a curled and crumpled appearance. Microscopically, the monolayer of granulosa cells sandwiched between their basement membrane and vitelline membrane also progressively disintegrated. At several places the epithelial sheets detached from the membranes. The number of apoptotic cells evaluated in haematoxylin-eosin (H\&E) stained sections (Figure 2d) amounted at culture time $24 \mathrm{~h}$ to $0.5 \pm 0.1 \%, 4.7 \pm 1.3 \%$ SEM at $48 \mathrm{~h}$ culture time and reached a maximum at $72 \mathrm{~h}$ $(10.5 \pm 1.4 \%$ SEM). Surprisingly the number declined afterwards $(7.1 \pm 2.1 \%$ SEM) (see Table 1$)$. On the vitallystained sheets counting of apoptotic cells was not reliable due to the curled and crumpled appearance of the sheets, which hampered focusing (Figure 2e). In situ end-labeling confirmed the data obtained on H\&E stained sections, moreover a number of nuclei with normal chromatin configuration on H\&E stained sections were positive after in situ end-labeling (Figure 2f). Electron microscopy at 48, 72 and $96 \mathrm{~h}$ revealed that some apoptotic bodies were engulfed by adjacent viable granulosa cells while most were undergoing secondary necrosis as is usually the case

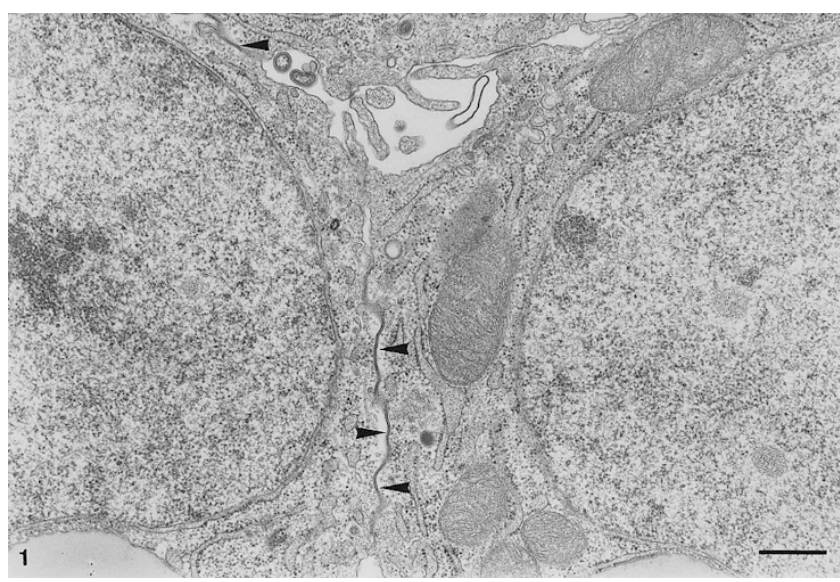

Figure $1 \mathrm{GC}$-sheet after $24 \mathrm{~h}$ culture in serum-free medium. Normal appearance of cytoplasm and nuclei, large gap junctions between neighbouring granulosa cells (arrowheads). Mag: $\times 24000$, Bar: $0.5 \mu \mathrm{m}$. in in vitro systems. Gap junctions became less abundant and smaller when compared to the $24 \mathrm{~h}$ cultures. Cells surviving at $96 \mathrm{~h}$ showed normal nuclei and (near) normal structure of mitochondria, endoplasmic reticulum and numerous ribosomes (Figure 3 ).

In cultures supplemented with FSH $(100 \mathrm{ng} / \mathrm{ml})$ the apoptotic process could be markedly reduced. At culture times 48,72 and $96 \mathrm{~h}$ counts on H\&E sections resulted in respectively $2.3 \pm 0.8$ SEM, $3.0 \pm 1.1$ SEM and $3.9 \pm 1.3 \%$ SEM of apoptotic nuclei (see Table 1)

\section{$\left[\mathrm{Ca}^{2+}\right]_{\mathrm{i}}$ measurements}

$\left[\mathrm{Ca}^{2+}\right]_{\mathrm{i}}$ was measured in acutely isolated granulosa cell sheets and in sheets kept for 24, 48, 72 and $96 \mathrm{~h}$ in serumfree culture. Moreover $\left[\mathrm{Ca}^{2+}\right]_{\mathrm{i}}$ was measured in cell sheets kept for $72 \mathrm{~h}$ in serum-free culture medium to which FSH $(100 \mathrm{ng} / \mathrm{ml})$ was added. Before the start of the calibration procedure, the preparations were stimulated by superfusion during $4 \mathrm{~min}$ with the agonists carbachol $(1-10 \mathrm{mM})$, LH (1 $\mathrm{IU} / \mathrm{ml}$ ) and cAMP $(1-10 \mathrm{mM})$. In only one fourth of the tested preparations $(n=12)$ a response of $\left[\mathrm{Ca}^{2+}\right]_{i}$ could be monitored with carbachol. In contrast the non-specific agent DMSO (1$2 \%$ ) was able to elicit a small response in all sheets where the resting $\left[\mathrm{Ca}^{2+}\right]_{i}$ was not close to the saturation level of the calcium probe (Figure 4). Figure 4 demonstrates a typical trace of the ratio signal during stimulation with agonists and during calibration.

Resting $\left[\mathrm{Ca}^{2+}\right]_{\mathrm{i}}$ averaged $525 \pm 75 \mathrm{nM}(n=6)$ in acutely isolated granulosa cell sheets. In the $24 \mathrm{~h}$ culture group the range of measured $\left[\mathrm{Ca}^{2+}\right]_{i}$ values was much more smeared out, averaging $606 \pm 176 \mathrm{nM}(n=15)$. In one sheet the saturation level of fura-2 was reached, corresponding to a $\left[\mathrm{Ca}^{2+}\right]_{\mathrm{i}}$ level equal to or above $2500 \mathrm{nM}$. Twenty percent of the sheets showed a $\left[\mathrm{Ca}^{2+}\right]_{i}$ level above $1000 \mathrm{nM}$. A similar pattern was found in the $48 \mathrm{~h}$ cultures, where $17 \%$ of the sheets displayed a $\left[\mathrm{Ca}^{2+}\right]_{i}$ level above $1000 \mathrm{nM}$. However the distribution of the $\left[\mathrm{Ca}^{2+}\right]_{i}$ values in the latter cultures was not as continuous as in the $24 \mathrm{~h}$ cultures displaying only low and very high values. This can be due to the smaller size of the experimental group ( $n=6$ versus $n=15$ at $24 \mathrm{~h}$ ).

In the $72 \mathrm{~h}$ cultures the fraction of sheets with $\left[\mathrm{Ca}^{2+}\right]_{\mathrm{i}}$ above $1000 \mathrm{nM}$ had risen to $57 \%$. Again, only low and very high values were observed here. At $96 \mathrm{~h}$ culture all sheets showed a low $\left[\mathrm{Ca}^{2+}\right]_{\mathrm{i}}$ value, averaging $89.1 \pm 15.6 \mathrm{nM}$ $(n=7)$. From these data (summarized in Figure 5) it appears that the large fraction of sheets with a high $\left[\mathrm{Ca}^{2+}\right]_{\mathrm{i}}$ value correspond to a culture stage where apoptosis is at its maximum ( $72 \mathrm{~h}$ cultures). In $72 \mathrm{~h}$ cultures where apoptosis was inhibited by FSH, no sheets were found with $\left[\mathrm{Ca}^{2+}\right]_{\mathrm{i}}$ above $1000 \mathrm{nM}$; $\left[\mathrm{Ca}^{2+}\right]_{\mathrm{i}}$ averaged to $305 \pm 124 \mathrm{nM}$ $(n=6)$ in this group. This value is significantly lower $(p<0.025)$ than the $\left[\mathrm{Ca}^{2+}\right]_{i}$ level in the $72 \mathrm{~h}$ cultures without FSH i.e. $1340 \pm 412 \mathrm{nM}(n=7)$.

\section{Discussion}

The present study shows that apoptosis is induced by culturing granulosa cell sheets from adult untreated animals for $48 \mathrm{~h}$ under serum-free conditions. 
Electron microscopy, in situ end-labeling and acridine orange staining demonstrate that GC sheets cultured for up to $24 \mathrm{~h}$ under serum-free conditions provide a preparation of viable, non-apoptotic cells. Counts on H\&E revealed a percentage of apoptotic nuclei smaller than one. Gap junctions were numerous and large in these cultures while it is known that in freshly isolated avian granulosa they are rare (see Perry et al, 1978; D'Herde and Vakaet, 1992); their development in our in vitro model may be related to the presence of the basement membrane. Indeed base- ment membrane components, beside their substantial role in the maintenance and further propagation of granulosa cell differentiation in vitro, can stimulate de novo gap junction formation in these cells as was demonstrated by morphometrical analysis: the cell membrane occupied by gap junctions was 4-5 times greater in cells grown on basement membrane compared to freshly isolated cells (Amsterdam et al, 1989).

Keeping the GC sheets in serum-free culture for a period longer than $24 \mathrm{~h}$ elicited manifest apoptosis with a
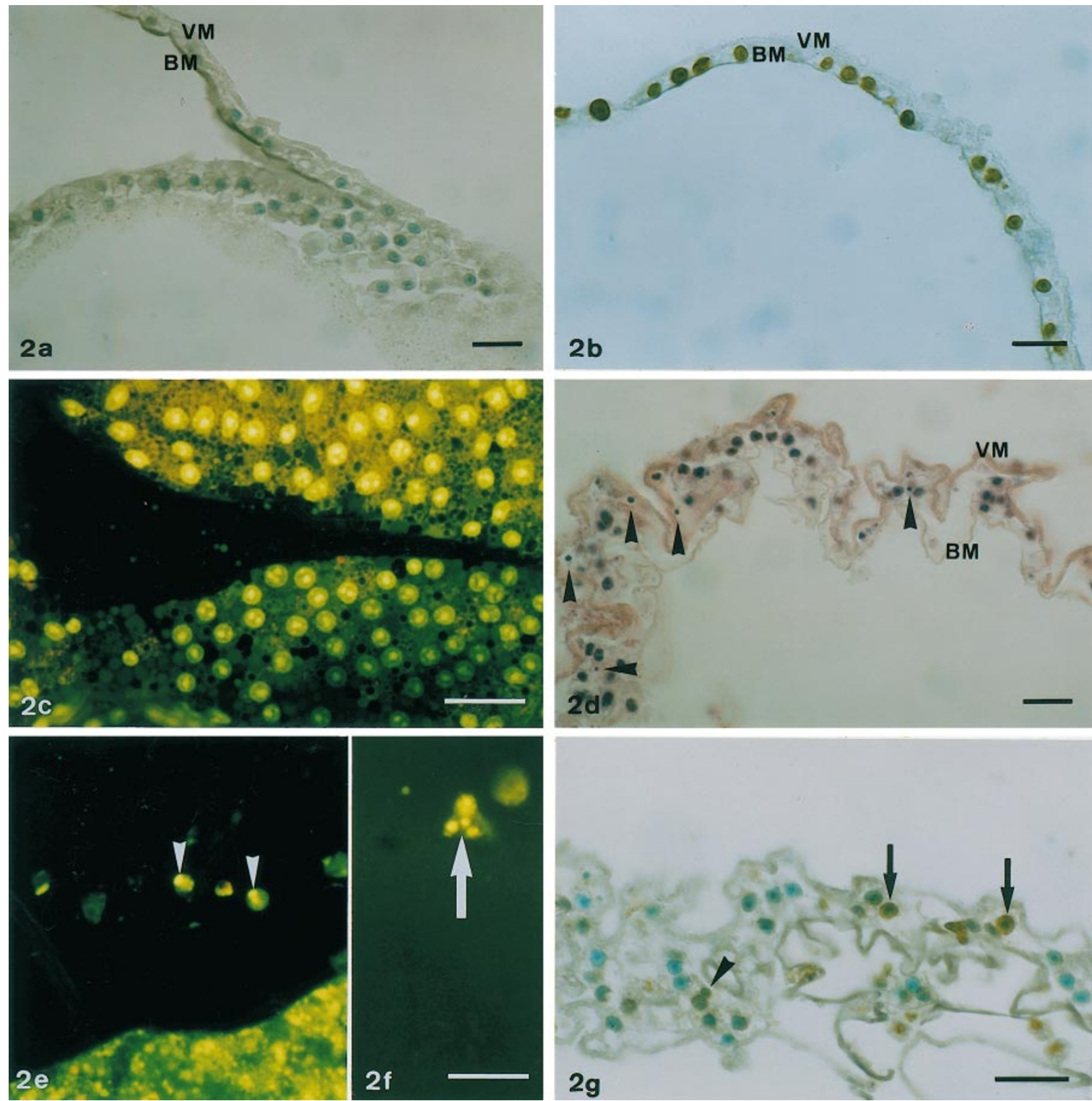

Figure 2 (a) GC-sheet after $24 \mathrm{~h}$ culture in. In situ 3'-end labeling of DNA (brown reactionproduct and methylgreen counterstaining); no evidence of DNA fragmentation. Mag: $\times 400$, Bar: $20 \mu \mathrm{m}$. (b) Positive control with DNAse treatment. In situ end-labeling of DNA fragments; all nuclei are accessible to the incorporating enzyme, indicating that absence of staining in a is due to absence of DNA fragmentation. VM: vitelline membrane, BM: basement membrane, Mag: $\times 500$, Bar: $20 \mu \mathrm{m}$. (c) GC-sheet after $24 \mathrm{~h}$ culture. Supravital staining with acridine orange reveals typical appearance of normal quail nuclei characterized by a centrally placed, large nucleolus-associated heterochromatin mass. Mag: $\times 560$, Bar: $20 \mu \mathrm{m}$. (d) GC-sheet after $72 \mathrm{~h}$ culture, H\&E stained $3 \mu \mathrm{m}$ section. Many GC's are detached from the basement membrane (BM); the vitelline membrane (VM) and BM are highly wrinkled. In between normal nuclei are a number of condensed chromatin masses of apoptotic nuclei (arrowheads). Mag: $\times 400$, Bar: $20 \mu \mathrm{m}$. (e-f) GC-sheet after $72 \mathrm{~h}$ culture, acridine orange staining. Condensation of chromatin (arrowheads) and fragmentation of nuclei (arrow) in isolated cells. (e) GC-sheet itself, its curled aspect hampers focusing. Mag: $\times 560$, Bar: $20 \mu \mathrm{m}$. (g) GC-sheet after $72 \mathrm{~h}$ culture. In situ $3^{\prime}$-end-labeling of DNA fragments (brown reactionproduct and methylgreen counterstaining). Labeling at the periphery of a condensed chromatin mass (arrowhead). Remark also the presence of labeling in nuclei with normal structure (arrows) Mag: $\times 560$, Bar: $20 \mu \mathrm{m}$. 
Table 1 Frequency of apoptotic nuclei as a function of culture time and expressed as the percentage of total nuclei counted in the same microscopic fields of H\&E stained sections (mean+SEM of five and three separate experiments)

\begin{tabular}{ccc}
\hline & $\begin{array}{c}\text { Serum-free cultures } \\
\mathbf{n = 5}(\%)\end{array}$ & $\begin{array}{c}\text { FSH supplemented cultures } \\
\mathbf{n = 3}(\%)\end{array}$ \\
\hline $24 \mathrm{~h}$ & $0.5+0.1$ & $0.5+0.3$ \\
$48 \mathrm{~h}$ & $4.7+1.3$ & $2.3+0.8$ \\
$72 \mathrm{~h}$ & $10.5+1.4$ & $* 3.0+1.1$ \\
$96 \mathrm{~h}$ & $7.1+2.1$ & $3.9+1.3$ \\
\hline
\end{tabular}

*Means significantly different from the data in the serum-free $72 \mathrm{~h}$ culture group with $p<0.01$.

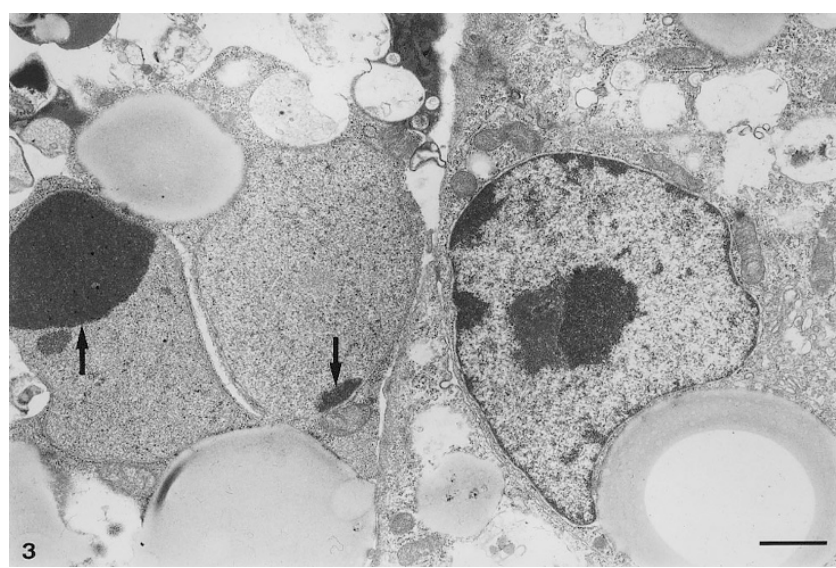

Figure 3 GC-sheet after $96 \mathrm{~h}$ culture. Two apoptotic nuclear fragments with marginated condensed chromatin (arrows), adjacent cell has normal nucleus Although the cytoplasm shows vacuoles, there is near normal morphology of mitochondria, endoplasmic reticulum and numerous ribosomes. Mag: 12000, Bar: $1 \mu \mathrm{m}$.

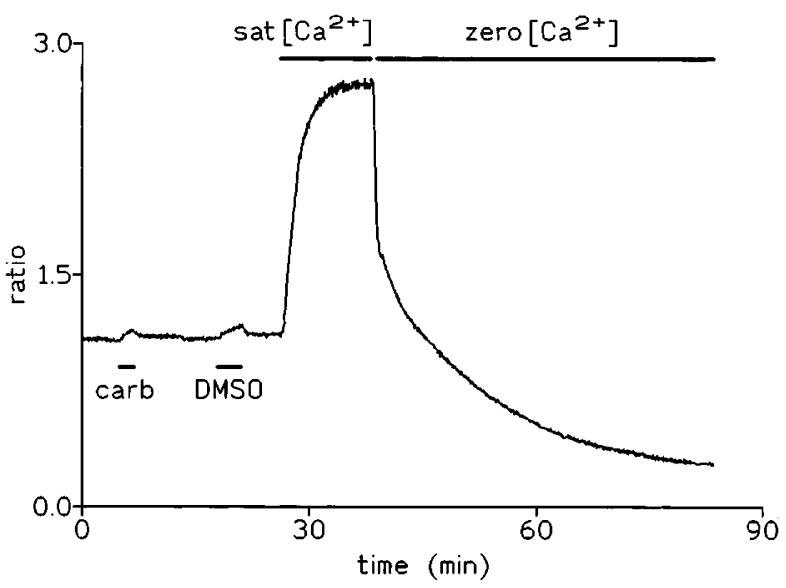

Figure 4 Time course of change of the fura-2 fluorescence ratio signal, measured as a mean signal over a subregion in a granulosa cell sheet, during stimulation with carbachol (carb, $10 \mathrm{mM}$ ) or DMSO (1 mM) and during calibration. Calibration involves sequential superfusion of the preparation with a solution that saturates fura-2 (sat. $\left.\left[\mathrm{Ca}^{2+}\right]\right)$ and with a solution that contains no free calcium (zero $\left[\mathrm{Ca}^{2+}\right]$ ).

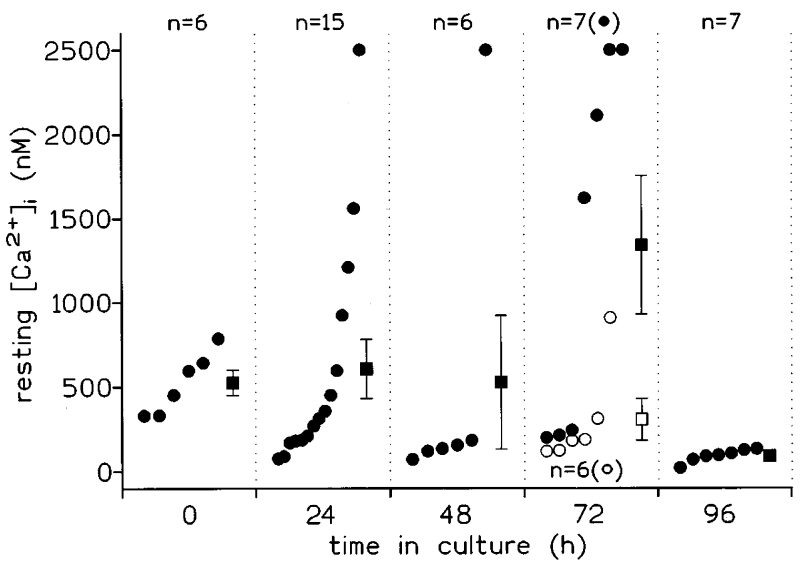

Figure 5 Plot of the resting $\left[\mathrm{Ca}^{2+}\right]_{\mathrm{i}}$ levels in granulosa cell sheets in function of the culture time. Individual measurements are represented by the filled circles, ordered from low to high values. The mean of each culture group is represented by the filled squares; the wiskers show the SEM. The open circles and squares in the $72 \mathrm{~h}$ culture group show measurements with FSH added to the culture medium. $\left[\mathrm{Ca}^{2+}\right]_{i}$ values in this group were significantly lower $(\mathrm{p}<0.025)$ compared to $72 \mathrm{~h}$ culture without FSH.

maximum occurring at $72 \mathrm{~h}$. This time sequence differs from the model of apoptosis using dissociated large granulosa cells from immature rat, in which manifest apoptosis already appeared after $24 \mathrm{~h}$ of serum-free culture in $50 \%$ of the cells (Luciano et al, 1994). The apoptosis-free period observed in our study is comparable to in vivo situations and may be related to the presence of both basement membrane and intercellular junctions in the GC sheet preparation. The presence of basement membrane can suppress the appearance of apoptosis in mammary epithelial cells (Boudreau et al, 1995). Peluso and Pappalardo (1994) have reported that, in their cultures of dissociated granulosa cells, significantly less apoptosis occurred in reaggregated cells connected by gap junctions. Recently the same group (Peluso et al, 1996) reported evidences that the anti-apoptotic action of cell contact in reaggregated GC's is not due to the presence of gap junctions, but is mediated by adhesiontype junctions.

Bursch et al (1990) calculated that, if the apoptotic process takes $3 \mathrm{~h}$ to complete one must only find 2 to $3 \%$ of the cells in a tissue to be undergoing apoptosis at any one time to obtain a very substantial cell loss of approximately $25 \%$ in $24 \mathrm{~h}$.

If the duration of the apoptotic process in our in vitro system can be compared to the latter data from in vivo systems than one can calculate that $10.5 \%$ apoptotic nuclei at culture stage $72 \mathrm{~h}$ (without FSH) will result in a cell loss of over $50 \%$ in the next $24 \mathrm{~h}$. We found a lower number of apoptotic nuclei in the $96 \mathrm{~h}$ culture $(7.1 \%)$ which indicates the progressive selection of a subpopulation of GC's which accommodates to serum-free culture and hormone deprivation. For the granulosa of preovulatory hen follicles it has been shown by multiparameter flow cytometry that two subpopulations do exist in a ratio of one to four; they differ 
in protein and RNA contents, size, cell cycle characteristics and DNA stainability (Marrone and Crissman, 1987). Interestingly in the mammalian model also (Luciano et al, 1994) a fraction of GC's was not triggered by serum-free culture to develop apoptosis.

The presence of apoptosis in the GC sheets extending over several days, while in each cell the process of apoptotic degeneration takes only $3 \mathrm{~h}$, points to asynchronous triggering throughout the sheet, and thus is comparable to what is observed in in vivo models: for example apoptosis induced in the ventral prostate gland by castration (Colombel and Buttyan, 1995). Including FSH in the culture medium inhibited apoptosis in the present model system as expected from its in vivo effects (Billig et al, 1994). Inhibition of spontaneous apoptosis by FSH was demonstrated in cultured rat follicles (Tilly and Tilly, 1995), but not yet in model systems containing only granulosa cells.

From the agonists tested, only carbachol and DMSO resulted in a $\left[\mathrm{Ca}^{2+}\right]_{i}$ response. In dissociated single chicken granulosa cells $\left[\mathrm{Ca}^{2+}\right]_{\mathrm{i}}$ transients could be evoked by $\mathrm{LH}$ and cAMP as well (Hertelendy et al, 1989; Morley et al, 1992; Morley and Whitfield, 1994). A possible explanation for the lack of response in our experiments can be that only a fraction of the cells responds to these agonists, which is presumably not detected in average measurements over a hundred cells as performed in the present experiments. Another explanation is that the appropriate receptors are lost during culture.

Calcium measurements in acutely isolated granulosa cell sheets showed a resting $\left[\mathrm{Ca}^{2+}\right]_{i}$ value of $525 \mathrm{nM}$. This is rather high when compared to the $100 \mathrm{nM}$ reported by Morley et al (1992) for dissociated and cultured GC's of chicken $\mathrm{F} 1$ follicles. It is slightly above the $355 \mathrm{nM}$ observed in freshly dissociated GC's of chicken F1 follicles (Hertelendy et al, 1989). Keeping the granulosa cell sheets for $24 \mathrm{~h}$ in culture elicited in one fifth of the sheets high $\left[\mathrm{Ca}^{2+}\right]_{\mathrm{i}}$ values. At this culture stage there was no manifest apoptosis, suggesting that the increased $\left[\mathrm{Ca}^{2+}\right]_{i}$ is involved in triggering apoptosis that is to appear $24 \mathrm{~h}$ later. Luciano et al (1994) have also reported hat apoptosis is preceded by a transient increase of $\left[\mathrm{Ca}^{2+}\right]_{i}$ using a model of serumfree culture of dissociated rat granulosa cells. The $\left[\mathrm{Ca}^{2+}\right]_{i}$ levels at the $24 \mathrm{~h}$ culture stage were equal to or higher than the $\left[\mathrm{Ca}^{2+}\right]_{\mathrm{i}}$ levels that have been reported to precede apoptosis in other model systems (McConkey et al, 1989a: 320-811 nM; McConkey et al, 1990: $457 \mathrm{nM}$; Bellomo et al, 1992: $600 \mathrm{nM}$ ).

$\left[\mathrm{Ca}^{2+}\right]_{\mathrm{i}}$ at culture stage $72 \mathrm{~h}$ was significantly lower when $\mathrm{FSH}$ was included in the culture medium. As $\mathrm{FSH}$ also inhibited apoptosis, this suggests a correlation between apoptosis and $\left[\mathrm{Ca}^{2+}\right]_{\mathrm{i}}$. Finally at $96 \mathrm{~h}$ of culture $\left[\mathrm{Ca}^{2+}\right]_{\mathrm{i}}$ attained a normal value of approximately $90 \mathrm{nM}$. At this culture stage the apoptotic process was subsiding, suggesting that the surviving small fraction of cells is resistant to the serum-free culture conditions and hence do not undergo apoptosis.

Taken together the present data suggest that apoptosis is initiated at high calcium foci within the granulosa cell layer at the $24 \mathrm{~h}$ serum-free culture stage. The high $\left[\mathrm{Ca}^{2+}\right]_{i}$ at 48 and $72 \mathrm{~h}$ can be interpreted as either initiating apoptosis or else as a consequence of the apoptotic process. Further experimental work aimed at correlating the calcium signal with markers of apoptosis at the level of individual cells will be needed to gain deeper insight in the relationship between $\left[\mathrm{Ca}^{2+}\right]_{i}$ and apoptosis in the presently used model.

\section{Materials and Methods}

\section{Isolation and culture of GC sheets}

GC sheets were prepared from ovarian follicles of adult regularly laying Japanese quail (Coturnix coturnix japonica). The animals were reared under continuous artificial illumination, with food and water ad libitum. The monolayered granulosa layer of the largest preovulatory follicle (F1) was isolated from the surrounding the cal covering in Krebs-Ringer equilibrated with a gas mixture of $80 \% \mathrm{O}_{2}$ and $20 \% \mathrm{CO}_{2}$, according to the technique described by Gilbert et al (1977). This method provides large sheets of vital GC's, sandwiched between their basement membrane and vitelline membrane. Granulosa cell sheets of circa $4 \mathrm{~mm}^{2}$ were maintained in $35 \mathrm{~mm}$ culture dishes under serumfree conditions for up to $96 \mathrm{~h}$ in humidified room air at $37^{\circ} \mathrm{C}$. The culture medium was M199 (Sigma, cat. no. M-039, Bornem, Belgium) supplemented with $0.1 \%$ bovine serum albumin (fraction V, Sigma, cat. no. A-4503, Bornem, Belgium), $6.0 \mathrm{~g} / \mathrm{l} \mathrm{HEPES,} 50 \mathrm{U} / \mathrm{ml}$ penicillin and $50 \mathrm{mg} / \mathrm{ml}$ streptomycin at $\mathrm{pH}$ 7.4. In order to inhibit the apoptotic process (Tilly and Tilly, 1995) culture medium was supplemented with $100 \mathrm{ng} / \mathrm{ml}$ sheep pituitary FSH (NIH-FSH-S17 U/mg Sigma, cat.no. F4520 ) in control cultures.

\section{Electron microscopy}

The granulosa cell sheets were fixed by immersion for $3 \mathrm{~h}$ in $2 \%$ glutaraldehyde and $1 \mathrm{mM} \mathrm{CaCl}_{2}$ buffered with $100 \mathrm{mM} \mathrm{Na}$-cacodylate (pH 7.4). After a rinse in $100 \mathrm{mM} \mathrm{Na-cacodylate} \mathrm{containing} 7.5 \%$ sucrose, the sheets were osmicated in $2 \% \mathrm{OsO}_{4}$ in $100 \mathrm{mM} \mathrm{Na}$ cacodylate and embedded in LX medium (Ladd, Burlington, VT, USA). Semithin sections were contrasted with toluidine blue. Ultrathin sections were stained with uranyl acetate and lead citrate.

\section{In situ end-labeling (ISEL) of DNA fragments}

In situ end-labeling was performed on paraffin sections of the GC sheets. DNA fragments were 3 '-end-labeled by use of the terminal transferase reaction (ApopTag S7100-kit, Oncor, Gaithersburg, MD, USA) according to a procedure described previously (D'Herde et al, 1994). Positive controls were first treated with DNase I to introduce DNA breaks in all nuclei.

\section{Staining of apoptotic nuclei}

Apoptotic nuclei were visualized by vital staining with acridine orange. A dye-mix working solution of $100 \mu \mathrm{g} / \mathrm{ml}$ acridine orange (BDH, Poole, UK) was prepared in normal buffer solution (NBS). The composition of NBS was as follows: $140 \mathrm{mM} \mathrm{NaCl}, 5 \mathrm{mM} \mathrm{KCl}$, $2.5 \mathrm{mM} \mathrm{CaCl}_{2}, 1.1 \mathrm{mM} \mathrm{MgCl}_{2}, 2.6 \mathrm{mM}$ dextrose and $10 \mathrm{mM} \mathrm{HEPES}$, $\mathrm{pH}$ 7.4. The GC sheets were superfused during $5 \mathrm{~min}$ with NBS 
containing $4 \mu \mathrm{g} / \mathrm{ml}$ acridine orange. After rinsing with NBS the GC sheets were examined with a $\times 40$ objective using a filter combination suitable for observing fluorescein.

\section{Quantification of apoptotic nuclei}

Apoptotic cells were identified by their characteristic morphological features as seen on $3 \mu \mathrm{m} \mathrm{H} \& \mathrm{E}$ stained sections. Apoptosis was scored in ten $100 \times$ randomly selected microscopic fields of an individual section and expressed as the number of apoptotic cells per number of total nuclei counted in the same microscopic fields. Depending on the culture time a total number of 500 to 750 nuclei were counted per GC sheet. Small groups of apoptotic bodies were counted as remnants of one apoptotic cell.

\section{Measurement of $\left[\mathrm{Ca}^{2+}\right]_{\mathrm{i}}$}

$\left[\mathrm{Ca}^{2+}\right]_{i}$ was measured using the calcium-sensitive fluorescent indicator fura-2 in combination with epifluorescence microscopy (Nikon Diaphot microscope, $\times 40$ oil immmersion objective). GC sheets (cultured for 24 or $48 \mathrm{~h}$ ) were loaded with fura-2 by incubating them in NBS containing $5 \mu \mathrm{M}$ fura-2 acetoxymethyl-ester (fura-2-AM, Molecular Probes, cat. no. F-1201, Eugene, OR, USA) and 0.01\% (w/ v) pluronic during $90 \mathrm{~min}$ at room temperature. GC sheets cultured for longer periods ( 72 and $96 \mathrm{~h}$ ) generally needed longer incubation times (120 $\mathrm{min}$ ) to obtain a measurable fluorescence signal. The loading solution also contained $2.5 \mathrm{mM}$ probenecid (Sigma, cat. no. P-8761, Bornem, Belgium) to prevent dye secretion (Di Virgilio et al, 1988). After loading, the GC sheets were rinsed twice and further incubated in NBS at $37^{\circ} \mathrm{C}$ during $1-2 \mathrm{~h}$ to ensure de-esterification. GC sheets were then ready for experiments. GC sheets were placed, one at a time, in the recording chamber and mechanically fixed using an overlaying grid of nylon threads attached to a metal ring. The recording chamber consisted of a Petri dish with a coverslip bottom. The GC sheet was submerged in a droplet of NBS; fresh NBS equilibrated with $100 \% \mathrm{O}_{2}$ and at room temperature entered the droplet at a rate of $1 \mathrm{ml} / \mathrm{min}$ via a pipette positioned close to the sheet. All reagents (e.g. agonists to stimulate the preparation, calibration solutions) were added via this superfusion pipette. Superfluous solution was drained via a second pipette inserted at the surface of the droplet and connected to a water jet pump. The volume of the droplet was kept constant at approximately $100 \mu \mathrm{l}$.

$\left[\mathrm{Ca}^{2+}\right]_{\mathrm{i}}$ was determined from the fluorescence ratio resulting from excitation with light at 340 and $380 \mathrm{~nm}$. A detailed description of the setup can be found in Leybaert et al (1993). Once a stable baseline ratio signal was established, the preparation was stimulated by superfusion with the agonists carbachol (Sigma, cat. no. C-4382, Bornem, Belgium), 8-Br-cAMP (Sigma, cat. no. B-7880, Bornem, Belgium), luteinizing hormone (LH) (Human choriongonadotrophin, Pregnyl $\left({ }^{\mathrm{R}}\right)$, ampoules $1500 \mathrm{IU}$, Organon, Belgium) or with the nonspecific agonist dimethyl-sulfoxide (DMSO) (DMSO for gas chromatography, Merck, Darmstadt, Germany). After this stimulation protocol, an in situ calibration procedure was carried out. This involved superfusion of the preparation with a fura-2 saturating solution (containing $145 \mathrm{mM}$ $\mathrm{KCl}, 10 \mathrm{mM} \mathrm{CaCl} 2,10 \mathrm{mM} \mathrm{HEPES}$ at $\mathrm{pH}$ 7.4) and consecutively with a calcium-free solution (containing $145 \mathrm{mM} \mathrm{KCl}, 10 \mathrm{mM}$ EGTA, $10 \mathrm{mM}$ HEPES at $\mathrm{pH} 7.4$ ) both in combination with $20 \mu \mathrm{M}$ of the calcium ionophore 4-Br-A-23187 (Molecular Probes, cat. no. B-1404, Eugene, OR, USA). This procedure allowed to determine $R_{\max }, R_{\min }$ and $\beta$, required to convert the fluorescence ratio to $\left[\mathrm{Ca}^{2+}+\right]_{\mathrm{i}}$ using the formula described by Grynkiewicz et al (1985). A dissociation constant of $224 \mathrm{nM}$ was used for the binding of fura-2 with calcium. The dynamic range of the ratio measurements $\left(R_{\max } / R_{\text {min }}\right)$, which gives an idea of the degree of de-esterification of the calcium probe, was not different between the different culture stages; it averaged $9.89 \pm 1.74$ (mean \pm SEM) over all measurements $(n=47)$. Comparison of the fluorescence level between fura-2 loaded GC sheets and solutions with known fura-2 (pentapotassium salt) concentrations suggest an intracellular fura-2 concentration below $50 \mu \mathrm{M}$.

\section{Statistical analysis}

Statistical significance was tested using the Mann-Whitney U-test, a non-parametric test for unpaired observations. A $p$ value less than 0.05 was considered as statistically significant (one-tailed test).

\section{Acknowledgements}

The authors are indebted to Guido De Pestel, Noel Verweire, Guido Van Limbergen and Betty De Prest for excellent technical assistance, moreover we thank BDP for compiling the bibliography. This study was supported by the Belgian NFWO (Krediet aan navorsers to K.D. no 31511695).

\section{References}

Amsterdam A, Rotmensch S, Furman A, Venter EA and Vlodavsky I (1989) Synergistic effect of human chorionic gonadotropin and extracellular matrix on in vitro differentiation of human granulosa cells: progesterone production and gap junction formation. Endocrinology 124: 1956-1964

Baffy G, Miyashita T, Williamson JR and Reed JC (1993) Apoptosis induced by withdrawal of interleukin-3 (IL-3) from an IL-3-dependent hematopoietic cell line is associated with repartitioning of intracellular calcium and is blocked by enforced Bcl-2 oncoprotein production. J. Biol. Chem. 268: 6511-6519

Bansal N, Houle AG and Melnykovych G (1990) Dexamethasone-induced killing of neoplastic cells of lymphoid derivation: lack of early calcium involvement. J. Cell. Physiol. 143: 105-109

Bellomo G, Perotti M, Taddei F, Mirabelli F, Finardi G, Nicotera P and Orrenius S (1992) Tumor necrosis factor alpha induces apoptosis in mammary adenocarcinoma cells by an increase in intranuclear free $\mathrm{Ca}^{2+}$ concentration and DNA fragmentation. Cancer Res. 52: 1342-1346

Billig H, Huruta I and Hsueh AJW (1994) Gonadotropin-releasing hormone directly induces apoptotic cell death in the rat ovary: biochemical and in situ detection of deoxyribonucleic acid fragmentation in granulosa cells. Endocrinology 134: 245252

Boudreau N, Sympson CJ, Werb Z and Bissell MJ (1995) Suppression of ICE and apoptosis in mammary epithelial cells by extracellular matrix. Science 267: $891-$ 893

Bursch W, Kleine L and Tenniswood M (1990) The biochemistry of cell death by apoptosis. Bioch. Cell. Biol. 68: 1071-1074

Chun S-Y, Billig H, Tilly JL, Furuta I, Tsafriri A and Hsueh AJW (1994) Gonadotropin suppression of apoptosis in cultured preovulatory follicles: mediatory role of endogenous insulin-like growth factor I. Endocrinology 135: 1845-1853

Cohen JJ and Duke RC (1984) Glucocorticoid activation of a calcium-dependent endonuclease in thymocyte nuclei leads to cell death. J. Immunol. 132: 38-42

Colombel MC and Buttyan R (1995) Hormonal control of apoptosis: the rat prostate gland as a model system. Methods in Cell Biology 46: 369-385

Corcoran GB, Fix L, Jones DP, Treinen Moslen M, Nicotera P, Oberhammer FA and Buttyran R (1994) Contemporary issues in toxicology. Apoptosis: Molecular control point in toxicity. Toxicol. Appl. Pharmacol. 128: 169-181

D'Herde K, De Pestel G and Roels F (1994) In situ end labeling of fragmented DNA in induced ovarian atresia. Biochem. Cell. Biol. 72: 573-579

D'Herde K and Vakaet L (1992) Study of yolk precursor transport in the avian ovary with the use of horseradish peroxidase. Int. J. Dev. Biol. 36: 435-438

Di Virgilio F, Steinberg TH, Swanson JA and Silverstein SC (1988) Fura-2 secretion and sequestration in macrophages. A blocker of organic aniontransport reveals that these processes occur via a membrane transport system for organic anions. J. Immunol. 140: 915-920 
Eisenhauer KM, Chun SY, Billig H and Hsueh AJW (1995) Growth hormone suppression of apoptosis in preovulatory rat follicles and partial neutralization by insulin-like growth factor binding protein. Biol. Reprod. 53: 13-20

Escargeuil-Blanc I, Salvayre R and Négre-Salvayre A (1994) Necrosis and apoptosis induced by oxidized low density lipoproteins occur through two calcium-dependent pathways in lymphoblastoid cells. FASEB J. 8: 1075-1080

Galli C, Meucci O, Scorziello A, Werge TM, Calissano P and Schettini G (1995) Apoptosis in cerebellar granule cells is blocked by high $\mathrm{KCl}$, Forskolin, and IGF-1 through distinct mechanisms of action: the involvement of intracellular calcium and RNA synthesis. J. Neurosci. 15: 1172-1179

Gilbert AB, Evans AJ, Perry MM and Davidson MH (1977) A method for separating the granulosa cells, the basal lamina and the theca of the preovulatory ovarian follicle of the domestic fowl (Gallus domesticus). J. Reprod. Fertil. 50: 179-181

Greenwald G and Terranova P (1988) Follicular selection and its control, in the physiolgy of reproduction, in Knobil E, Neill JD, Ewing LL, Greenwald GS and Markert C eds. (NY: Raven Press) pp. 387-446

Grynkiewicz G, Poenie M and Tsien RY (1985) A new generation of $\mathrm{Ca}^{2+}$ indicators with greatly improved fluorescence properties. J. Biol. Chem. 260: 3440-3450

Hertelendy F, Nemecz G and Molnar M (1989) Influence of follicular maturation on leuteinizing hormone and guanosine $5^{\prime}$-O-thiotriphosphate-promoted breakdown of phosphoinositides and calcium mobilization in chicken granulosa cells. Biol. Reprod. 40: 1144-1151

Hughes Jr FM and Gorospe WC (1991) Biochemical identification of apoptosis (Programmed cell death) in granulosa cells: Evidence for a potential mechanism underlying follicular atresia. Endocrinology 129: 2415-2422

Jones DP, McConkey DJ, Nicotera P and Orrenius S (1989) Calcium-activated DNA fragmentation in rat liver nuclei. Biol. Chemistry 264: 6398-6403

KroemerG, PetitP,Zamzami N, Vayssiére JL and MignotteB(1995) The biochemistry of programmed cell death. FASEB J. 9: 1277-1287

Leybaert L, De Ley G and De Hemptinne A (1993) Effects of flunarizine on induced calcium transients as measured in fura-2 loaded neurons of the rat dorsal root ganglion. Naunyn-Schmiedeberg's Arch. Pharmacol. 348: 269-274

Luciano AM, Pappalardo A, Ray C and Peluso JJ (1994) Epidermal growth factorinhibits large granulosa cell apoptosis by stimulating progesterone synthesis and regulating the distribution of intracellular free calcium. Biol. of Reprod. 51:646-654

Marrone BL and Crissman HA (1987) Characterization of granulosa cell subpopulations from avian preovulatory follicles by multiparameter flow cytometry. Endocrinology 122: $651-658$

Martikainen P and Isaacs J (1990) Role of calcium in the programmed death of rat prostatic glandular cells. The Prostate 17: 175-187

McConkey DJ, Nicotera P, Hartzell P, Bellomo G, Wyllie AH and Orrenius S (1989a) Glucocorticoids activate a suicide process in thymocytes through an elevation of cytosolic $\mathrm{Ca}^{2+}$ concentration. Arch. Biochem. Biophys. 269: 365-370

McConkey DJ, Hartzell P, Nicotera P and Orrenius S (1989b) Calcium-activated DNA fragmentation kills immature thymocytes. FASEB J. 3: 1843-1849

McConkey DJ, Chow SC, Orrenius S and Jondal M(1990) NK cell-induced cytotoxicity is dependent on $\mathrm{Ca}^{2+}$ increase in the target. FASEB J. 4: 2661-2664

McConkey DJ, Aguilar-Santelises M, Hartzell P, Eriksson I, Mellstedt H, Orrenius S and Jondal M (1991) Induction of DNA fragmentation in chronic B-lymphocytic leukemia cells. J. Immunol. 146: 1072-1076
McConkey DJ, Nicotera Pierluigi and Orrenius S (1994) Signalling and chromatin fragmentation in thymocyte apoptosis. Immunol. Rev. 142: 343-363

Morley $P$ and Whitfield JF (1994) Effect of tamoxifen on carbachol-triggered intracellular calcium responses in chicken granulosa cells. Cancer Res. 54: 69-74

Morley P, Tsang BK, Whitfield JF and Schwartz J-L (1992) The effect of muscarinic cholinergic agonists on intracellular calcium and progesterone production by chicken granulosa cells. Endocrinology 130: 663-670

Nicotera P, Bellomo G and Orrenius S (1992) Calcium-mediated mechanisms in chemically induced cell death. Ann. Rev. Pharmacol. Toxicol. 32: 449-470

Ojcius DM, Zychlinski A, Zheng LM and Young JDE (1991) lonophore-induced apoptosis: role of DNA fragmentation and calcium fluxes. Exp. Cell. Res. 197: 4349

Orrenius S and Nicotera P (1994) The calcium ion and cell death. J. Neural. Transm. 43: $1-11$

Peluso JJ and Pappalardo A (1994) Progesterone and cell-cell adhesion interact to regulate rat granulosa cell apoptosis. Biochem. Cell. Biol. 72: 547-551

Peluso JJ, Pappalardo A, Trolice MP (1996) N-cadherin-mediated cell contact inhibits granulose cell apoptosis in a progesterone-independent manner. Endocrinology 137: $1196-1203$

Perotti M, Toddei F, Mirabelli F, Vairetti M, Bellomo G, McConkey DJ and Orrenius S (1990) Calcium-dependent DNA fragmentation in human synovial cells exposed to cold shock. FEBS Lett. 59: 331-334

Perry MM, Gilber AB and Evans AJ (1978) Electron microscope observations on the ovarian follicle of the domestic fowl during the rapid growth phase. J. Anat. 125: $481-497$

Takei Nand Endo Y (1994) $\mathrm{Ca}^{2+}$ ionophore-induced apoptosis in cultured embryonic rat cortical neurons. Brain Res. 652: 65-70

Tilly JL, Kowalski KI, Johnson AL and Hsueh AJW (1991) Involvement of apoptosis in ovarian follicular atresia and postovulatory regression. Endocrinology 129: 2799 2801

Tilly JL, Billig H, Kowalski KI and Hsueh AJW (1992) Epidermal growth factor and basic fibroblast growth factor suppress the spontaneous onset of apoptosis in cultured rat ovarian granulosa cells and follicles by a tyrosine kinase-dependent mechanism. Mol. Endocrinol. 6: 1942-1950

Tilly JL and Tilly KI (1995) Inhibitors of oxidative stress mimic the ability of folliclestimulating hormone to suppress apoptosis in cultured rat ovarian follicles. Endocrinology 136: 242-252

Tilly JL, Tilly KI, Kenton ML and Johnson AL (1995) Expression of members of the Bcl-2 gene family in the immature rat ovary: Equine chorionic gonadotropin-mediated inhibition of granulosa cell apoptosis is associated with decreased bax and constitutive Bcl-2 and Bcl-Xlong messenger ribonucleic acid levels. Endocrinology 136: $232-241$

Trump BF and BerezeskyIK (1995) Calcium-mediated cell injury and cell death. FASEB J. 9: $219-228$

Tsafriri A and Braw RH (1984) Experimental approaches to atresia in mammals. Oxford Reviews of Reproductive Biol. 6: 226-265

Zeleznik AJ, Ihrig LL and Bassett SG (1989) Developmental expression of $\mathrm{Ca}^{++} / \mathrm{Mg}^{++}$. dependent endonuclease activity in rat granulosa and luteal cells. Endocrinology 125: $2218-2220$ 